\title{
Review \\ A Review of Reactor Designs for Hydrogen Storage in Clathrate Hydrates
}

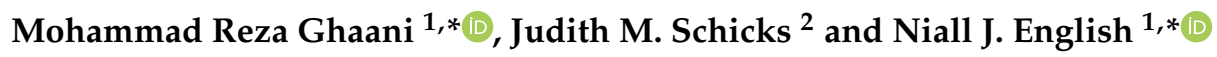 \\ 1 School of Chemical and Bioprocess Engineering, University College Dublin, Belfield, 4 Dublin, Ireland \\ 2 GFZ German Research Centre for Geosciences, Telegrafenberg, 14473 Potsdam, Germany; \\ judith.schicks@gfz-potsdam.de \\ * Correspondence: mohammad.ghaani@ucd.ie (M.R.G.); niall.english@ucd.ie (N.J.E.); \\ Tel.: +353-1-716-1758 (M.R.G.); +353-1-716-1646 (N.J.E.); Fax: +353-1-716-1177 (N.J.E.)
}

check for updates

Citation: Ghaani, M.R.; Schicks, J.M.; English, N.J. A Review of Reactor Designs for Hydrogen Storage in Clathrate Hydrates. Appl. Sci. 2021, 11,469. https://doi.org/10.3390/ app11020469

Received: 29 October 2020 Accepted: 22 December 2020 Published: 6 January 2021

Publisher's Note: MDPI stays neutral with regard to jurisdictional clai$\mathrm{ms}$ in published maps and institutional affiliations.

Copyright: (C) 2021 by the authors. Licensee MDPI, Basel, Switzerland. This article is an open access article distributed under the terms and conditions of the Creative Commons Attribution (CC BY) license (https:// creativecommons.org/licenses/by/ $4.0 /)$.

\begin{abstract}
Clathrate hydrates are ice-like, crystalline solids, composed of a three-dimensional network of hydrogen bonded water molecules that confines gas molecules in well-defined cavities that can store gases as a solid solution. Ideally, hydrogen hydrates can store hydrogen with a maximum theoretical capacity of about $5.4 \mathrm{wt} \%$. However, the pressures necessary for the formation of such a hydrogen hydrate are 180-220 MPa and therefore too high for large-scale plants and industrial use. Thus, since the early 1990s, there have been numerous studies to optimize pressure and temperature conditions for hydrogen formation and storage and to develop a proper reactor type via optimisation of the heat and mass transfer to maximise hydrate storage capacity in the resulting hydrate phase. So far, the construction of the reactor has been developed for small, sub-litre scale; and indeed, many attempts were reported for pilot-scale reactor design, on the multiple-litre scale and larger. The purpose of this review article is to compile and summarise this knowledge in a single article and to highlight hydrogen-storage prospects and future challenges.
\end{abstract}

Keywords: hydrogen storage; clathrate hydrate; reactor design; Water-Spraying Reactor; Stirred-Tank Reactor; Bubbling Reactor; Water-In-Oil Emulsion; Fixed-Bed Reactor; unidirectional growth

\section{Introduction}

Increasing $\mathrm{CO}_{2}$ content in the atmosphere, and the associated global warming and climate change, are making more and more people think about an alternative and $\mathrm{CO}_{2-}$ neutral energy use. A prominent example is the "European Green Deal" put forward by the President of the European Commission Ursula von der Leyen, where Europe aims at becoming the world's first climate-neutral continent by 2050. Such a tremendous challenge can only be realised when all promising approaches with regard to energy generation, storage and distribution are tested and applied. Power-to-gas is one approach considered to store surplus power produced by wind or solar cells as gas: solar or wind power will be used to produce $\mathrm{H}_{2}$ by electrolysis of water. At this point, the question of further use or storage of this green' $\mathrm{H}_{2}$ arises. The storage methods currently under discussion for $\mathrm{H}_{2}$ as a result of a power-to-gas scenario are the (1) liquefaction of hydrogen, (2) feeding of small quantities into existing natural gas pipelines, (3) geological storage, and (4) liquid organic hydrogen carriers (LOHC). All methods have disadvantages: (1) $\mathrm{H}_{2}$ liquefaction requires high pressures $(70 \mathrm{MPa})$ and low temperatures $\left(-250^{\circ} \mathrm{C}\right)$ also for the duration of $\mathrm{H}_{2}$ storage as liquid phase which is highly energy intensive and equivalent up to $40 \%$ of the stored energy [1], (2) the feeding of $\mathrm{H}_{2}$ in the existing natural gas system is currently limited to max. $10 \%$, (3) for geological storage of $\mathrm{H}_{2}$, as a mobile and reactive molecule, specific geological requirements have to be fulfilled (which limits the number of potential underground deposits), and (4) $\mathrm{H}_{2}$ storage in LOHCs uses aromatic hydrocarbons such as toluene, which have to be chemically synthesised and are often harmful to health and environment. In 
addition, LOHC require catalysts or/and elevated pressures and temperatures [2]. A different, promising approach could be the storage of $\mathrm{H}_{2}$ in clathrate hydrates.

Clathrate hydrates are ice-like, crystalline solids, composed of a three-dimensional network of hydrogen bonded water molecules that confines gas molecules in well-defined cavities [3], as shown in Figure 1. Considerable amounts of gas can be stored in clathrate structures as a solid solution: approximately $164 \mathrm{~m}^{3}$ of gas can be stored in $1 \mathrm{~m}^{3}$ gas hydrate at $273.15 \mathrm{~K}$ and $0.1 \mathrm{MPa}$. In general, non-polar gas molecules that have to have a certain size in order to shield the forces of attraction of the water molecules and to stabilize the water cages are encased into the clathrate structures. Depending on the size of the hydrate-forming gas molecules, different clathrate hydrate structures such as structure I, structure II and structure $\mathrm{H}$ have been identified. However, for a long time, the $\mathrm{H}_{2}$ molecule was considered to be too small to stabilize the water lattices in any hydrate structure and was therefore not considered as a hydrate former [3]. Following work of Dyadin et al. in 1999, Mao et al. confirmed that $\mathrm{H}_{2}$ is also able to form gas hydrates with structure II [2].

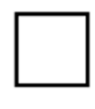

0

0

0

0

3

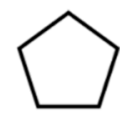

12

12

12

12

6

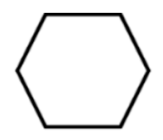

\section{2}
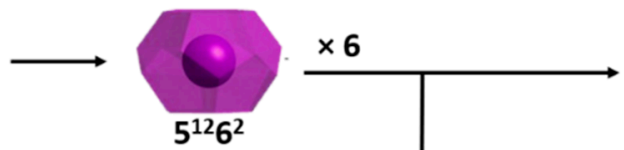

4

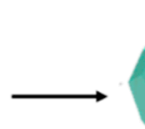

0

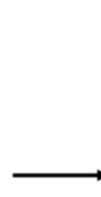

8
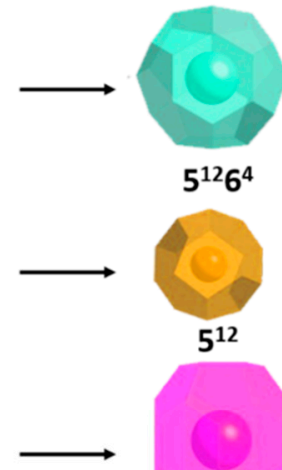

$5^{12} 6^{4}$

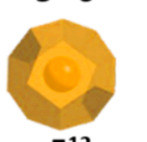

$5^{12}$

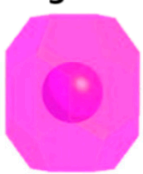

$5^{12} 6^{8}$

3

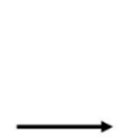

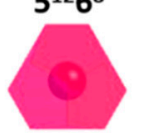

$4^{3} 5^{6} 6^{3}$

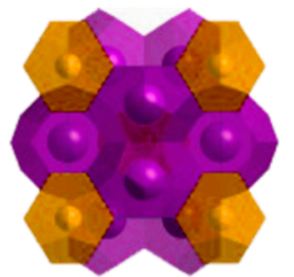

sl $\left(34 \mathrm{H}_{2} \mathrm{O}\right)$

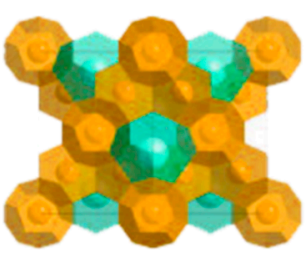

sll $\left(136 \mathrm{H}_{2} \mathrm{O}\right)$

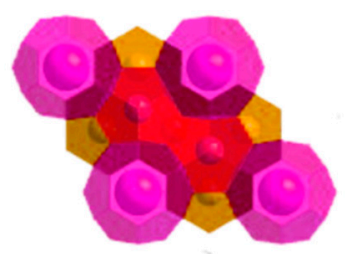

sH $\left(34 \mathrm{H}_{2} \mathrm{O}\right)$

Figure 1. Schematic of sI and sII polymorphs with host lattice shown in terms of $5^{12}, 5^{12} 6^{2}$ and $5^{12} 6^{4}$ cages. In sI, two small $5^{12}$ pentagonal dodecahedral cavities and six larger tetrakaidecahedral $5^{12} 6^{2}$ cages define the unit cell of 46 water molecules. For sII, each unit cell contains 136 water molecules and 24 cages: 16 small $5^{12}$ pentagonal dodecahedral cavities and 8 larger $5^{12} 6^{4}$ hexakaidecahedrons.

Since, unlike other gas hydrates, several $\mathrm{H}_{2}$ molecules can occupy a water cage, an approximate $\mathrm{H}_{2} / \mathrm{H}_{2} \mathrm{O}$ molar ratio of $1: 2$, corresponding to a $\mathrm{H}_{2}$ storage capacity of about $5.4 \mathrm{wt} \%$ can be achieved as a theoretical upper limit for maximal cage occupancy-double in small and quadruple in large sII-lattice cavities [4]. However, this is controversial, and disputed by many in the neutron-scattering and condensed-matter-theory communities.

The advantages of $\mathrm{H}_{2}$ storage in clathrate hydrates compared to all previously mentioned methods are manifold: (1) within the clathrate hydrate structure, the $\mathrm{H}_{2}$ molecule is stored in the solid phase, decreasing the mobility and reactivity of the escharotic $\mathrm{H}_{2}$ molecule, (2) for the formation of $\mathrm{H}_{2}$ hydrate, only water is needed in addition to $\mathrm{H}_{2}$, (3) since there are no chemical bonds between the $\mathrm{H}_{2}$ molecule and the hydrate structure, only 
physical parameters such as temperature or pressure have to be changed to release the $\mathrm{H}_{2}$, and (4) the storage of $\mathrm{H}_{2}$ in clathrate hydrates can be applied anywhere, ideally close to the location of $\mathrm{H}_{2}$ production, and (5) enormous amounts of $\mathrm{H}_{2}$ can be released from clathrate hydrates within very short times under controlled conditions.

However, it is unfortunate that the formation of pure $\mathrm{H}_{2}$ hydrate with high $\mathrm{H}_{2}$ storage capacity is so far only possible in a diamond-anvil cell under very high pressures (>150 MPa) and only in small quantities (Mao et al., 2002).

In recent years, several researchers tried to modify and optimise the formation conditions of hydrates containing $\mathrm{H}_{2}$. One approach was to use an additional hydrate former which occupies some cavities of the hydrate structure and thus stabilizes it. The formation of a hydrate from water and $\mathrm{H}_{2}$ only results in a structure II hydrate phase. A unit cell of a structure II hydrate consists of two different cavity types, namely, 16 pentagonal dodecahedrons $\left(5^{12}\right)$ and 8 hexakaidecahedrons $\left(5^{12} 6^{4}\right)$. Large molecules, such as tetrahydrofuran (THF), are also known to form structure II hydrates with the $5^{12} 6^{4}$ cavities filled and the $5^{12}$ cavities empty at ambient pressure and temperatures $<277 \mathrm{~K}$. THF was therefore used to form a binary hydrate with $\mathrm{H}_{2}$ at moderate pressure (13.8 MPa) and temperature $(270 \mathrm{~K})$ conditions with the large cavities filled with THF and the small cavities filled with $\mathrm{H}_{2}$ [5].

This structure can be used as a 'molecular sieve' to separate hydrogen from a gas mixture. Zhong et al. [6] reported the first observation of the sieving behavior of a massive hydrate layer toward different gas molecules based on their different diffusion rates in THF hydrate. Hydrogen can penetrate a 5-mm thick THF hydrate layer in $24 \mathrm{~h}$ with a diffusion coefficient of $6.1 \times 10^{-12} \mathrm{~m}^{2} / \mathrm{s}$, while the THF hydrate is 'resistant' to $\mathrm{CH}_{4}$ and $\mathrm{CO}_{2}$ molecules.

For hydrogen-storage applications, unfortunately, the occupancy of the large cavities with a stabilising molecule results in a significant decrease of $\mathrm{H}_{2}$-storage capacity, which is limited to $1.06 \mathrm{wt} \%$ [7]. In addition, the $\mathrm{H}_{2}$-storage capacity varies strongly depending on the THF concentration and the applied pressure and temperature conditions [8]. The same is true for other structure II hydrate formers applied for the formation of $\mathrm{H}_{2}$ hydrates, such as cyclopentane, furan, 2,5-dihydrofuran, 1,3-dioxalane, tetrahydropyran, 1,4-dioxane, acetone, cyclohexanone, and methyl-cyclohexane.

It turned out that the $\mathrm{H}_{2}$ storage capacity was similar to that of using THF under identical operating conditions [8]. Slightly higher $\mathrm{H}_{2}$ capacities were observed for binary $\mathrm{H}_{2}$ hydrates with structure $\mathrm{H}$ when methyl-tert-butyl ether (MTBE) or dimethylcyclohexane $(\mathrm{DMCH})$ were used as stabilisers. In these cases, the $\mathrm{H}_{2}$ capacities ranged between $1.42 \mathrm{wt} \%$ (MTBE) and $1.37 \mathrm{wt} \%(\mathrm{DMCH})$, respectively [7]. Another approach used the different, purely synthetic hydrate structure VI for $\mathrm{H}_{2}$ storage, leading to promising results with regard to $\mathrm{H}_{2}$ capacities ( $5.18 \mathrm{wt} \% \mathrm{H}_{2}$ ). This structure VI, however, is not stable and transforms into structure II hydrates [7,9]. Recently, the formation of mixed gas hydrates form a gas mixture containing $\mathrm{H}_{2}, \mathrm{CH}_{4}$, and $\mathrm{C}_{2} \mathrm{H}_{6}$ was reported [10]. The additional hydrocarbons $\mathrm{CH}_{4}$ and $\mathrm{C}_{2} \mathrm{H}_{6}$ enable the formation of a mixed hydrate under moderate pressure and temperature conditions. However, the $\mathrm{H}_{2}$-storage capacity of the resulting mixed hydrate phase is in the range of the approaches mentioned above. In summary, the approach of using stabilising molecules has been successful in view of moderate pressure and temperature for formation and storage conditions. Unfortunately, the decrease of $\mathrm{H}_{2}$ capacity associated therewith, or the instability of the resulting hydrate structure (sVI), has reduced the attractiveness of the approach.

A different approach for hydrogen storage is the formation of semi-clathrates. These are typically ionic compounds, in which the cationic part occupies the cavities of the hydrate structure like a guest molecule, whereas the anionic part is included in the lattice structure along with the water molecules. Alkylammonium and alkylphosphonium salts, such as tetrabutylammonium bromide (TBAB), tetrabutylammonium chloride (TBAC), and tetrabutylphosphonium bromide (TBPB), are typical representatives used in the studies, because they facilitate hydrate formation close to room temperature and at moderate pressures. However, it turns out that the $\mathrm{H}_{2}$-storage capacity in TBAB semi-clathrate is lower 
vis-à-vis the occupancy of $\mathrm{H}_{2}$ in small cavities of sII hydrates. $\mathrm{H}_{2}$-storage capacity in TBPB and TBAC mixed hydrates was reported to be $0.16 \mathrm{wt} \%$ and $0.14 \mathrm{wt} \% \mathrm{H}_{2}$, respectively [8].

In addition to the issues related to formation of the hydrate, the hydrogen-insertion mechanism plays also a crucial role not only at a fundamental level, but also in view of potential applications. In a study reported by Nguyen et al., the enhancement of the $\mathrm{H}_{2}$ insertion within the THF hydrate achieved with the co-inclusion of acidic additive [11]. In gas hydrate structure, the acidic additive acts as a "flexibilizer" of the water cage through the addition of chemical water $\mathrm{H}$-bond defects - promoting $\mathrm{H}_{2}$ inter-cage diffusion [12].

It should also be noted that sample size in most of the experiments reported in literature was smaller than $20 \mathrm{~g}$. Trueba et al., as well as Veluswamy and Linga, conducted experiments with larger sample volumes of about $100 \mathrm{~g}$ using TBAB, TBAF, and THF, respectively [13-15]. The observed significantly lower $\mathrm{H}_{2}$-storage capacities, i.e., of the order of only $0.1 \mathrm{wt} \%$. Obviously, and problematically, this indicates serious mass- and heat-transfer issues which could not be resolved by continuous stirring of the sample.

To render $\mathrm{H}_{2}$ storage in clathrate hydrates more economically feasible, the following aspects must be addressed:

(1) Pressure and temperature conditions for the formation and storage of $\mathrm{H}_{2}$ hydrates have to be optimised. Ideally, the pressure should be less than $10 \mathrm{MPa}$ and the temperature around $0{ }^{\circ} \mathrm{C}$.

(2) The $\mathrm{H}_{2}$-storage capacity should be as high as possible (ideally approaching $\sim 5 \mathrm{wt} \%$ ).

(3) Any hydrate promoters should be eco-friendly and cheap.

To explore, and ultimately address, these issues, a greater understanding of the modes of action of promoter-additives is needed, as well as technical advances in the design of hydrate-formation reactors, embracing new concepts in hydrate formation. Both promoter and reactor have to optimise mass and heat transfer to achieve the abovementioned goals. According to the existing literature, the promoting additive has to reduce the gas-liquid interfacial tension, and thus increase mass transfer of the $\mathrm{H}_{2}$ and water molecules. In addition, the promotor should enhance crystallisation by 'pre-structuring' the water molecules. It should also be hydrophilic to be soluble into the aqueous phase, as well as eco-friendly.

In addition to on the usage of promoting substances, the development of proper reactors through optimisation of the heat and mass transfer for hydrate formation is also essential. So far, the construction of such hydrate-formation reactors has been targeted towards small, sub-litre scale; and indeed, many attempts have been reported for pilotscale reactor designs, on the multiple-litre scale and larger. In the ideal case, continuous formation of hydrate would be ideal for large hydrate production and gas storage application. Continuous flow (CF) synthesis has evolved into a very important tool in modern chemistry especially in organic and pharmaceutical applications [16-18]. The advantages offered by continuous flow chemistry include faster reactions, controlled and quicker optimization, cleaner products, in-line monitoring, and ease of scale up [19-22]. However, the applicability of flow chemistry in high-pressure gas reactors is limited due to the difficulty of discharge of the products and also controlling the pressure in different stages of the reactions. This review is designed to help any researcher aiming for the design of a prototype production facility for $\mathrm{H}_{2}$ hydrates, with optimised processes involving both reactor design and deployment of promoters.

\section{Hydrate-Formation Technologies}

The first step in the development of hydrate-based technologies for hydrogen storage involves the formation of hydrate structure as the host for capturing hydrogen molecules. The main difficulties during large-scale hydrate formation of hydrate is (1) well mixing of the supplied guest gas with water to overcome mass-transfer challenges, and (2) an optimum heat-transfer mechanism to dissipate the latent heat released due to hydrate formation must be present. It should be noted that the water solubility of hydrogen is very low compared to methane.

According to the literature, there are two main approaches in gas hydrates formation: 
- Gas dispersion introduced in water continuous phase, or;

- Liquid dispersion, which involves introducing water droplets in a high pressure gas chamber.

However, developing each type of above-mentioned technologies will have its own challenges. Gas dispersion is limited by large energy consumption when scaling up, whilst heat transfer (primarily latent-heat dissipation) will be the main drawback for scaling up liquid-dispersion techniques. Figure 2 presents the design approaches and philosophies discussed in the literature, which we shall examine in some detail in the following section.

\section{Hydrate-Formation Reactors}

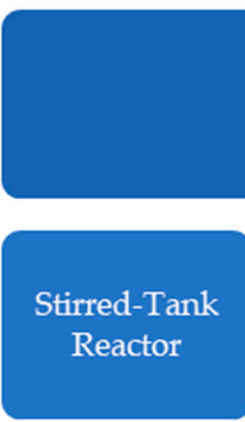

Gas Dispersion
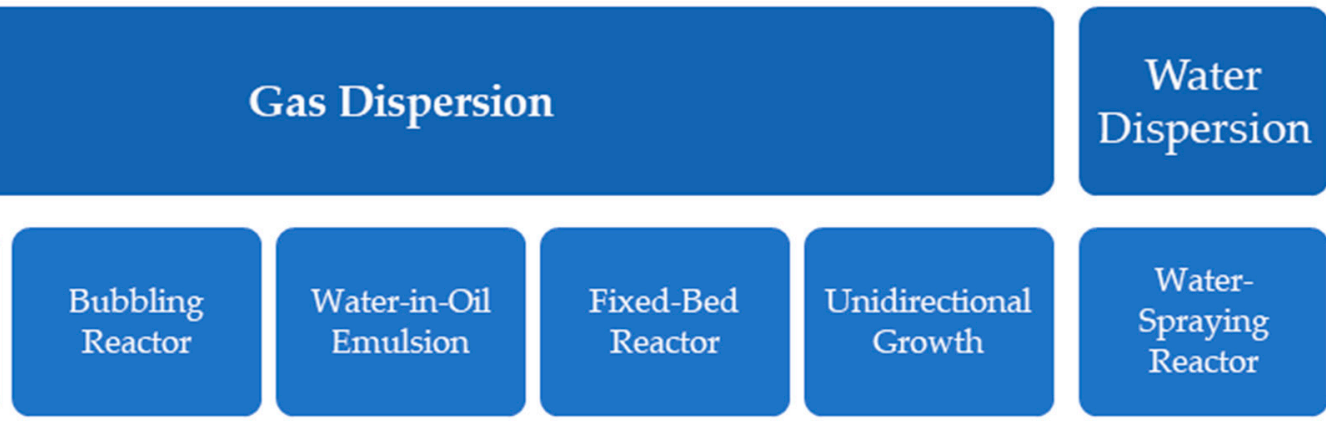

Water-

Spraying

Reactor

Figure 2. Developed hydrate formation techniques, categorised based on phase continuity.

\subsection{Stirred-Tank Reactor}

Continuous mixing of gas and water to improve both heat and mass transfer can be achieved by stirring. In a hydrate-formation, shortened induction, accelerated formation, and increased storage capacity are observed as the result of applied stirring $[23,24]$. In this system, high-pressure gas is introduced on the top of the liquid phase and mixed with water by an impeller. During the formation process the reactor temperature controls by the cooling system and the pressure and temperature of the liquid/gas will be logged into a computer and will be used to for further analysis (Figure 3). This set-up is made by four main components (1) gas supply, (2) high pressure reactor, (3) cooling and (4) data logging systems. Due to the simplicity in the design and operation factors, for the most fundamental studies such as thermodynamics and kinetics of gas hydrate formation/dissociation this family of the reactors have been widely used [23]. However, the use of stirring reactors involves the following main disadvantages:

- As slurry thickens the energy cost of stirring increases [24].

- Additional work required for hydrate/slurry separation, for hydrate packing in a storage vessel.

- Considerable amounts of interstitial water will remain between hydrate grains.

- Hindered scale-up. The required agitation power increases with the 5th power of the impeller size [25]. 


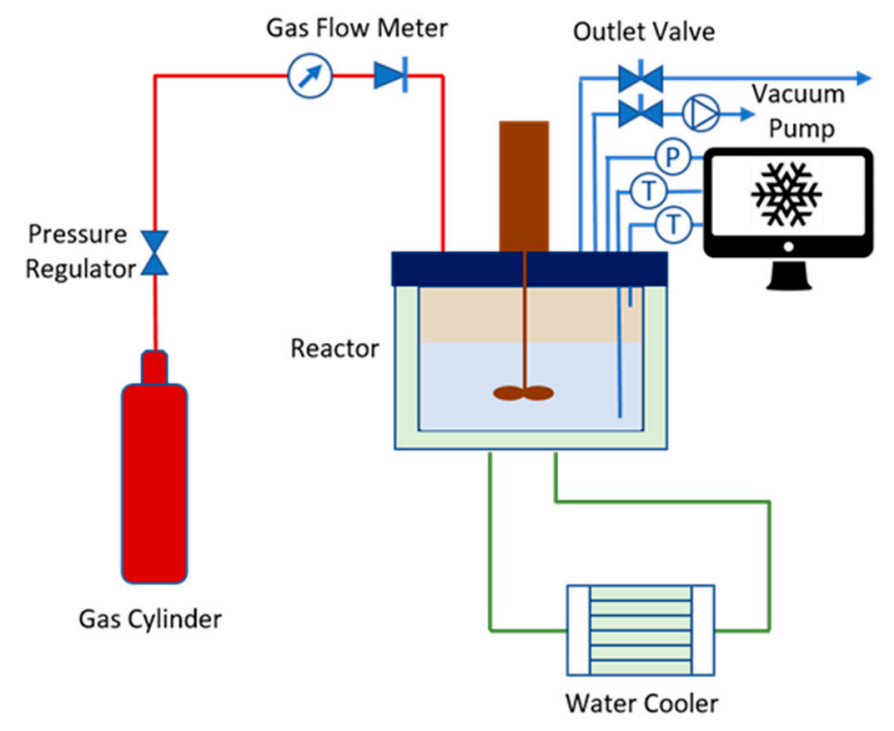

Figure 3. Standard stirred tank hydrate formation reactor.

\subsection{Bubble Forming}

The bubble-tower reactor is a known reactors developed for gas/liquid reactions in industrial application and found to be suitable for gas hydrate formation. Takahashi et al. [26] patented a microbubble technology for hydrate formation. This technology is developed based on the idea behind the ejector-type loop reactor (ELR). In ELR the kinetic energy of a high-velocity liquid jet is being used to the form microbubbles in the bulk fluid which will result to a full mixture of the gas and the liquid [27].

The advantages of using an ELR system over a stirred-tank reactor can be listed as [25]:

1. An enhanced gas and liquid mixing characteristics and mass transfer.

2. The possibility of using an external heat exchanger for controlling the liquid's temperature to avoid the disadvantages of using internal cooling coil installations.

3. Gas circulation provides the optimum use of the gas and eliminate the need for any additional gas compression step.

4. Easier operation and less sealing problems at high pressure due to the absence of moving parts in the design.

Figure 4a presents the ELR assisted hydrate-formation system. The details of the ejector are illustrated in Figure 4b. In the water-circulation system, the cooled-down liquid will be mixed with gas inside the ejector and introduced again to the bottom of the reactor through the diffuser.

Limited heat transfer rates during the hydrate formation and difficulty in the separation of formed hydrate at the gas/liquid interface constitute the main problems with this type of design, which can result in an overall lowering of efficiency of hydrate formation.

In the water-recirculation pathway, and during the heat-exchange process through the surface of smooth tube, the temperature near the inner wall was found to be lower than that in the centre of the tube. This will be followed by heterogeneous nucleation of hydrate on the surface of the internal wall. The adhesion of hydrate to the wall surface will decrease the heat-transfer efficiency and inhibit hydrate formation in the reactor. 
(a)

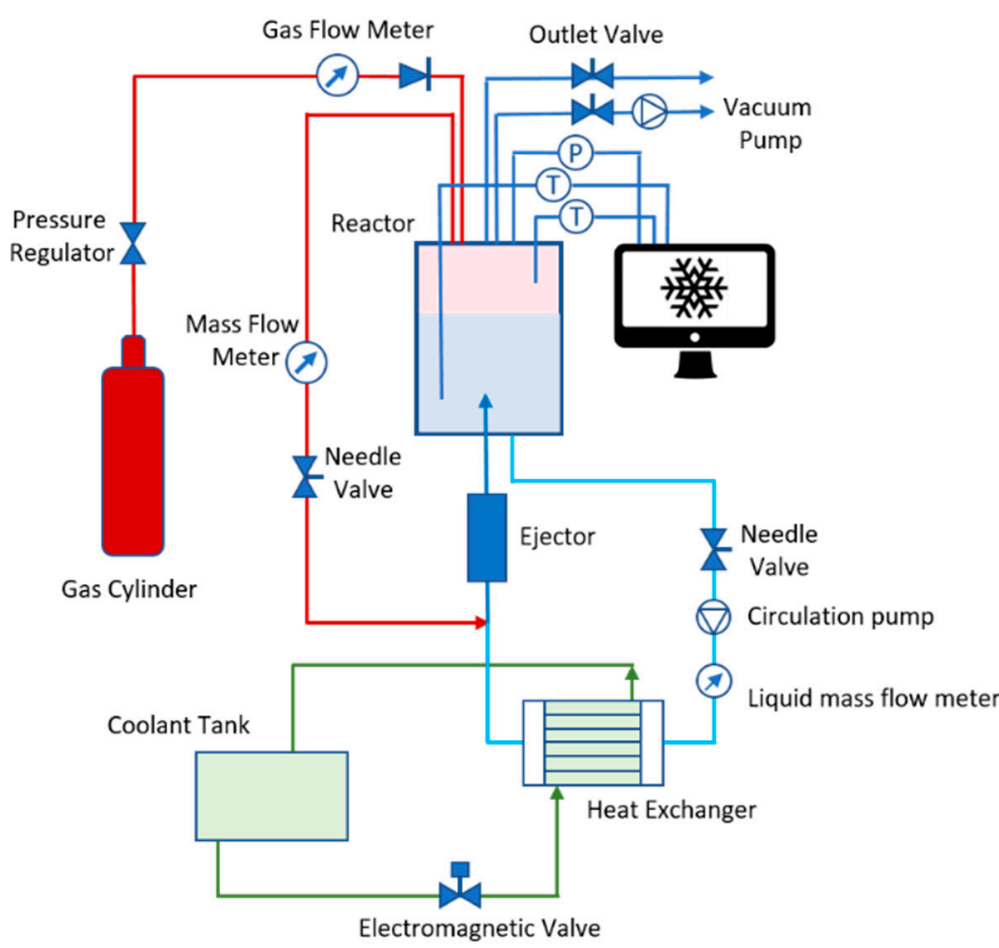

(b)

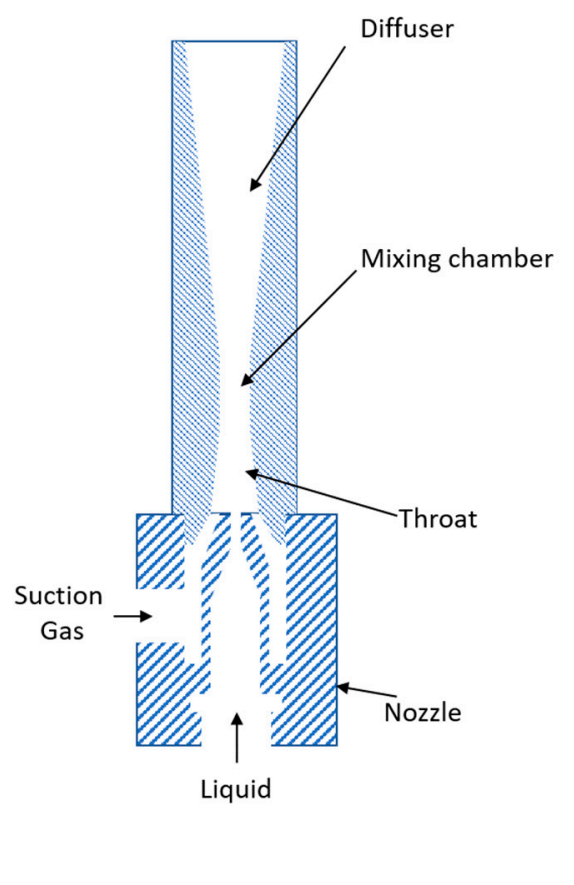

Figure 4. (a) Schematic plot of the hydrate formation system with ELR. (b) Scheme of the ejector.

Therefore, Wang et al. [28] proposed a new hydrate-preparation system under an endogenous force-field. In this design, instead of a smooth tube, a tube with an internal spiral groove was used (Figure 5) to generate a secondary flow and centrifugal force (endogenous force field) $[29,30]$. This force-field and the existing density difference between water, gas and hydrate, will cause the removal of the formed hydrate attached to the wall. On the other hand, an enhanced degree of heat-transfer of the fluid inside the tube was observed due to the production of secondary flow phenomena that also serves to increase the extent of synergism between the velocity and temperature fields [31-33].
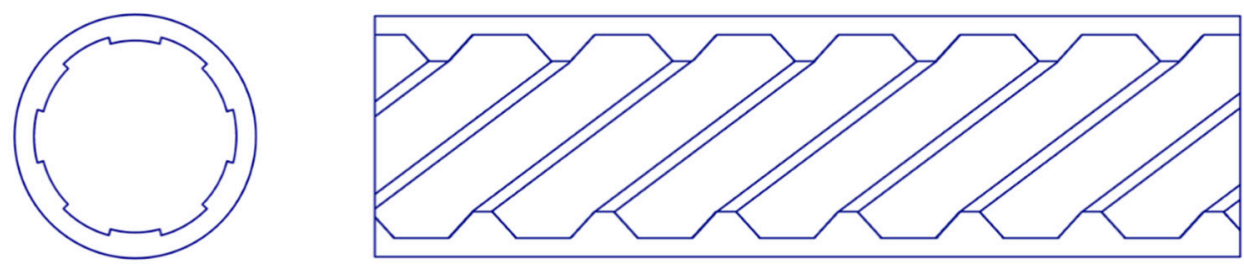

Figure 5. Schematic diagram of the internal spiral-grooved tube.

Finally, in this family of reactors, the use of gas nano-bubbles (including those of hydrogen) may also be an excellent way to increase surface-to-volume ratios of gas in water to facilitate the growth of hydrogen hydrate, and intimate gas-liquid contact [34].

As a result of surface design, the complex secondary flow and centrifugal force phenomenon, known as endogenous force-field, would be generated [29,30]. In the endogenous force-field, because of the density difference amongst the three phases (water/gas/hydrate), the gases near the wall of the tube and the hydrate attached to the wall could be removed. As a result of the rapid renewal of the gas-liquid and hydrate-wall interfaces, mass-transfer processes of hydrate-reaction systems were improved. Meanwhile, according to the fieldsynergy principle [31-33], the production of the secondary flow phenomenon increases the 
level of synergism between the velocity and temperature fields, as mentioned previously, and improves greatly the heat-transfer efficiency of the fluid inside the tube.

\subsection{Water-In-Oil Emulsion}

Compared with aqueous solutions, Liu et al. proposed a new method as the absorptionhydration hybrid separation method [35-38] in which water and oil emulsion was used for hydrate formation. In a water/oil emulsion, gas-water contact area is significantly increased due to the presence of nano-droplets of water in the oil phase, which will be followed by a high yield in gas-hydrate production. Furthermore, a good 'flowability' of formed hydrate/oil slurry can be achieved with the addition of a suitable anti-agglomerant agent. This can be a great breakthrough in which most of the difficulties in hydrate production, such as a low formation yield, slow kinetics, and difficulty in realizing a continuous production operation can be solved by using water/oil emulsion in hydrate production [35].

In the research presented by Di Profio and co-workers, a reverse-micelle process was used to enhance hydrogen-hydrate formation in minutes, using water-insoluble coguests [39]. The marked enhancement in hydrate-formation rate was due to a very substantial increase of surface-to-volume ratio of the water 'pseudo-phase'. Indeed, this general concept of an 'inverted phase' using oil emulsions as the continuous phase to manipulate surface-to-volume ratios [40] represents an intriguing advance in the formation of hydrogen hydrates, and the economics and operability of this process has been gauged, as well as hydrogen hydrate as a storage medium in general, relative to competing hydrogen-storage technologies, with largely favourable results [41].

In another design proposed by Murakami et al. [42], the operation was characterised by use of two liquid jets impinging on each other in a loaded reactor with high-pressure hydrate-forming gas (HFG) (Figure 6). Liquid water is ejected from one jet and, a hydrophobic liquid with a considerably low freezing point is coming from the second jet. In case of using a large-molecule guest substances (LMGSs) as the hydrophobic component, in addition to the main HFG, the liquid will serve as a companion hydrate guest, which will fit into the $5^{12} 6^{8}$ cages of the structure- $\mathrm{H}$ hydrates [43]. The schematic design of a twin-jet system is illustrated in Figure 6. To control the reaction temperature, each liquid component is being circulated after passing through heat exchangers and introduced into the high pressure chamber in a way that a rapidly expanding sheet will form at the point of liquids' collision in the gas area which will result in the formation of water/LMGS droplets in the gas phase [44]. Hydrate will crystalize in the surface of the droplets and will coalesce into a liquid pool, allowing for water and LMGS to be separated due to a different density profile at the top and bottom of the hydrate layer.

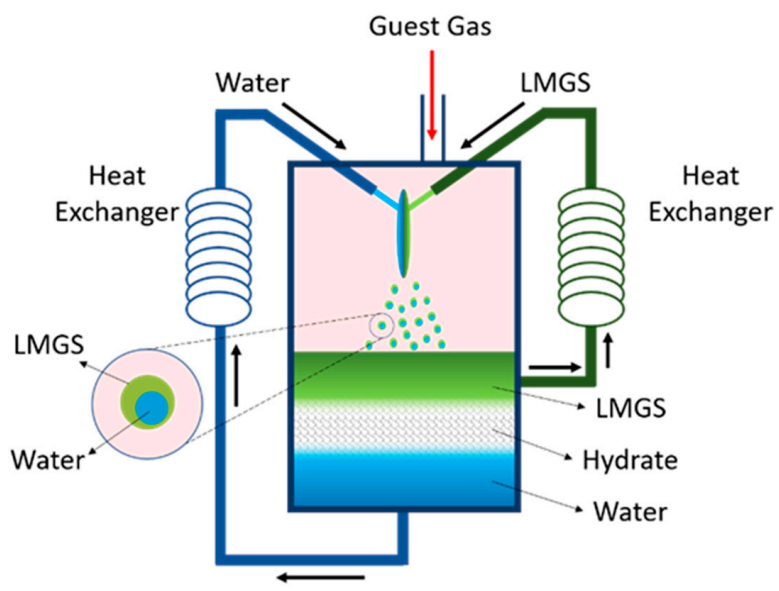

Figure 6. Conceptual illustration of a twin-jet hydrate-forming system. 
Major disadvantages of conventional water-spray systems, such as (a) a relatively large power consumption for pressurizing water to be sprayed, and (b) an insufficient function of discharging heat released by the hydrate formation will be eliminated by using a twin-jet scheme, liquid circulation and external heat exchangers (Figure 6) [42].

\subsection{Fixed-Bed Reactor}

The fixed-bed reactor (FBR) configuration is known for its ability in significantly enhancing the kinetics of hydrate formation in hydrate-based gas-separation applications [45-49]. It has to be mentioned that the experimental apparatus for FBR experiments is the same as unstirred/stirred reactor, except for the fact that in the FBR setup, a porous medium is located at the bottom of the reactor (Figure 7). FBR enhance the gas/liquid contact, provides more surface for hydrate nucleation and has the advantage of eliminating agitation as an energy-intensive and high-cost hydrate-formation step in stirred tank reactors. Extra surfaces can be provided by employing different porous media like silica gel, silica sand, lightweight and highly porous foam, metallic packing, and glass beads in FBR. The bed materials can be used repeatedly in many hydrate-formation cycles [45-47,50,51]. In a study published by Babu et al. [52], the diverse effects of different bed materials, such as sand, gel, and foam in a FBR scheme were compared with hydrate-formations rate using the standard stirred tank reactor configuration (Figure 7). It this work, the importance of the role of available surface and microstructure of the bed materials is discussed [52].

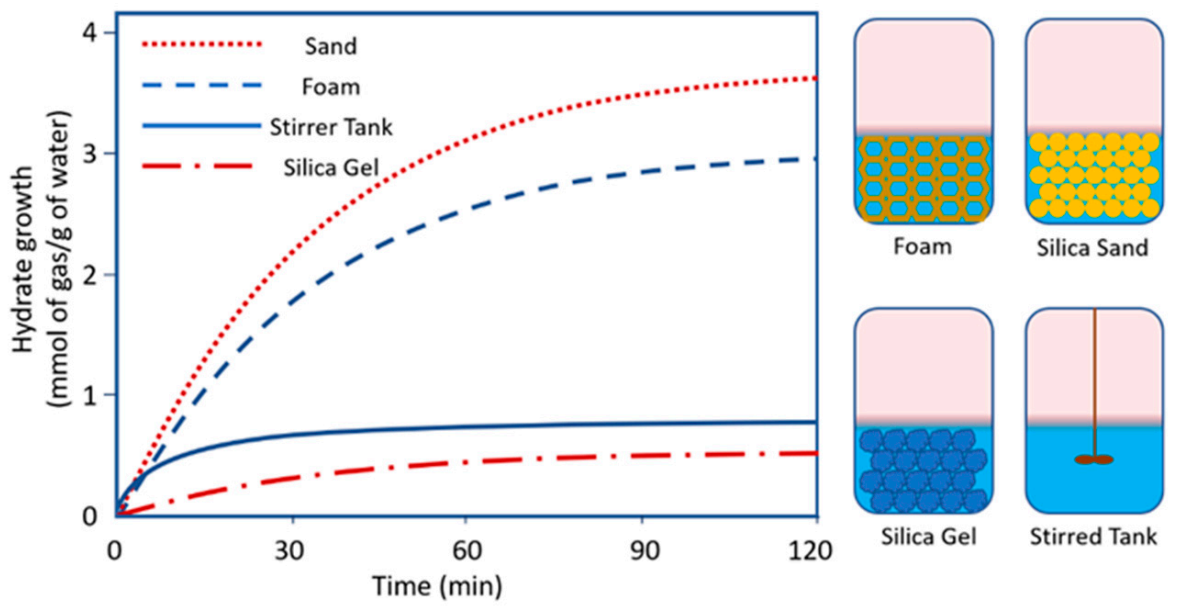

Figure 7. Hydrate-growth comparison between the stirred tank, silica gel, silica sand, and polyurethane foam.

It is worth mentioning that, although using a porous materials as the bed can enhance the kinetics of hydrate formation, the presence of added materials will cause some challenges in the final application of gas hydrates in gas-storage applications.

\subsection{Unidirectional Growth}

The unidirectional growth technique is known as a suitable set up for interfacial investigation in crystal-growth applications. Muraoka et al. [53] studied the formation of tetrahydrofuran (THF) hydrate from kinetic hydrate inhibitors aqueous solution using the unidirectional-growth technique. A conceptual drawing of a unidirectional-growth apparatus is presented in Figure 8. The reactor cell is made of two parallel stainless-steel plates separated by a silicon or metal spacer. Thermocouples are located horizontally along the length of reactor. Two connected tubes to the starting and the end of the chamber, are designed to provide the gas and cold water, respectively. The unidirectional growth apparatus will be provided by two heat exchanger blocks, the temperature of the first block is set to the values lower than the equilibrium temperature $\left(T_{\text {eq }}\right)$ and the other block is heated to a temperature higher than $\mathrm{T}_{\mathrm{eq}}$. The reactor chamber is placed between two sets 
of cold and hot blocks. The applied heating gradient due to the designed arrangement of the blocks can be measured by the array of the thermocouples mounted in the body of the reactor. Hydrate crystals can nucleate in the cold side of the reactor where the cold water is added into the chamber through the designed capillary. To observe hydrate growth, a step motor was used to pull the chamber towards the cold block at a constant velocity.

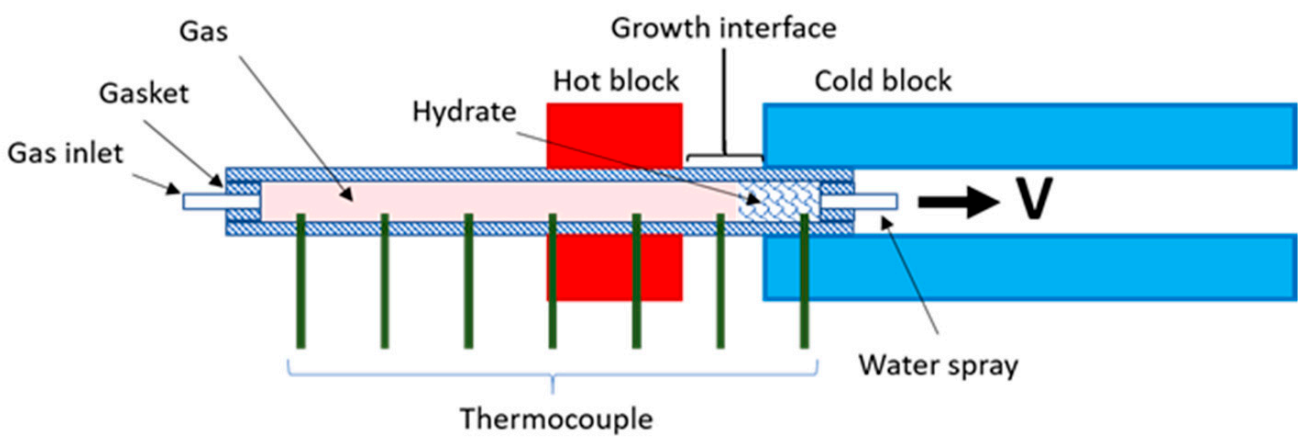

Figure 8. Schematics of unidirectional growth apparatus.

\subsection{Spraying Reactor}

Spraying liquid in a gas chamber is another method to mix two immiscible phases phase in a gas-liquid system. Mori et. al. studied the formation of methane hydrate in a spraying reactor by spraying water into a high-pressure methane container [54,55]. There were many attempts to develop the proposed setup by Mori, and to scaled-up systems, by Rossi et al. [56] and Li et al. [57]. Using this design (Figure 9), Li and his team studied different parameters on hydrate formation such as initial pressures, water volumes, gassupply modes, and nozzle-atomising angles by measuring the hydrate-formation rate, induction time, gas consumption, heat of formation, and gas-storage density.

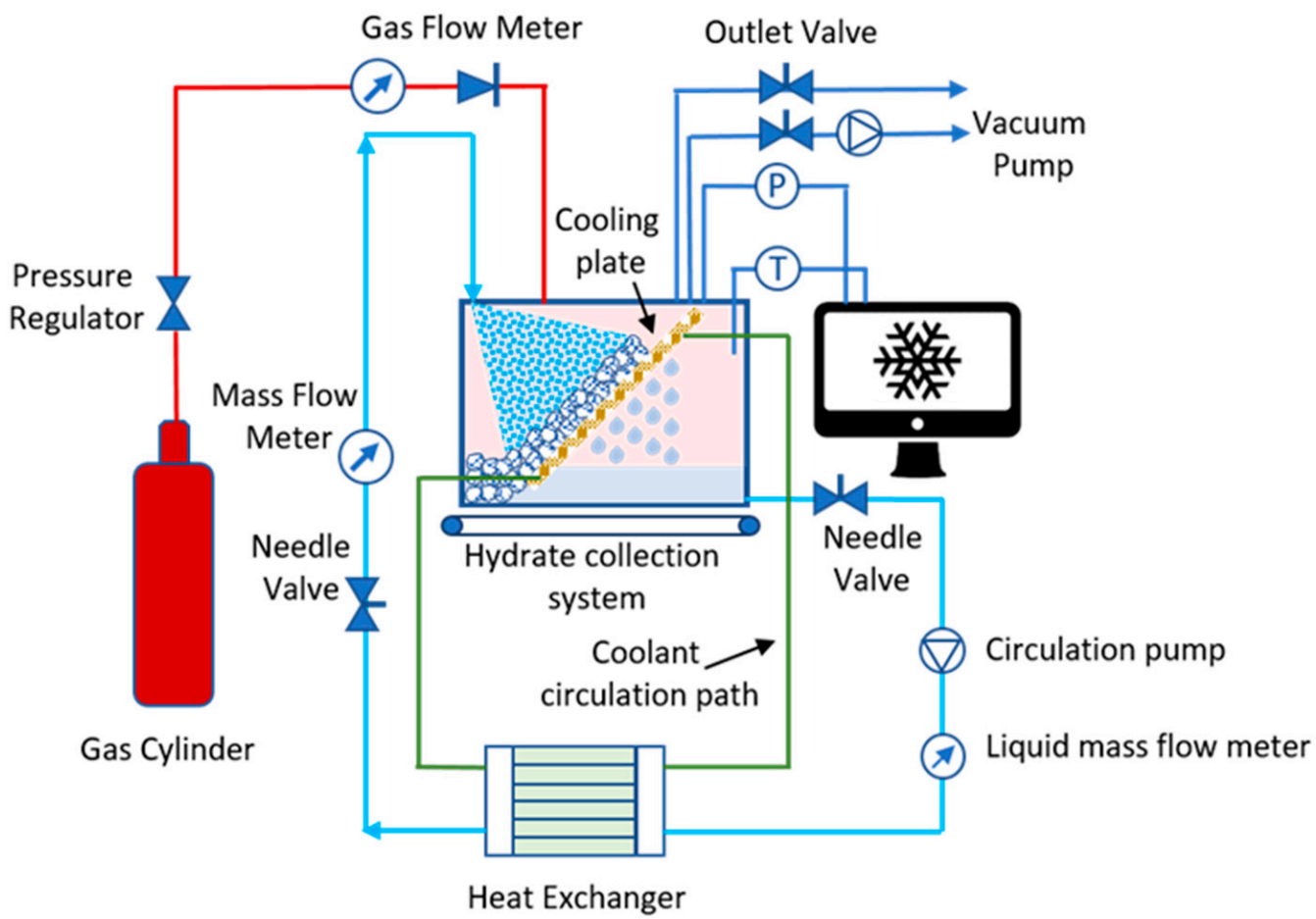

Figure 9. Experimental apparatus for water-spray design. 
The design is made by five main sub-systems:

1. Gas-supply: To supply gas and maintain the pressure.

2. Refrigeration system: To keep the reactor at low temperature by dissipating the released latent heat during hydrate formation.

3. Reactor chamber: The hydrate-formation chamber.

4. Spraying system: water sprays as small particles into the gas phase

5. Data-logging system: Pressure, temperature and mass flow will be recorded during the reaction time.

Increased the gas/water interfacial area and use of a simpler reactor design (with no need for mechanical stirrer) are the main advantages while the difficulty in dispensing the produced latent heat of hydrate formation, together with limited hydrate-to-water volume ratios, are identified as the main disadvantages of this design. Fukumoto [58] and Matsuda [59] suggested the use of a steadily-chilled copper block as the cooling plate in front of the spraying system inside the gas chamber to collect the released heat and minimize the heat-dispersion problem.

\subsection{High-Pressure Optical Cell}

To study the structure of hydrate via spectroscopy techniques such as Raman, in many studies, a small optical cell with and without gas flow is employed [60-64]. Figure 10 shows one of the designs used by Zhong et. al [6], where a hydrate forms between two sapphire windows, a resistance temperature detector (RTD) used for temperature measurement and the pressure of the chamber is installed on the gas inlet line on the top of the reactor. An external cooling channel was also designed to control the temperature of the reactor. In this design the whole volume of the hydrate-formation chamber is only $1.4 \mathrm{~mL}$.

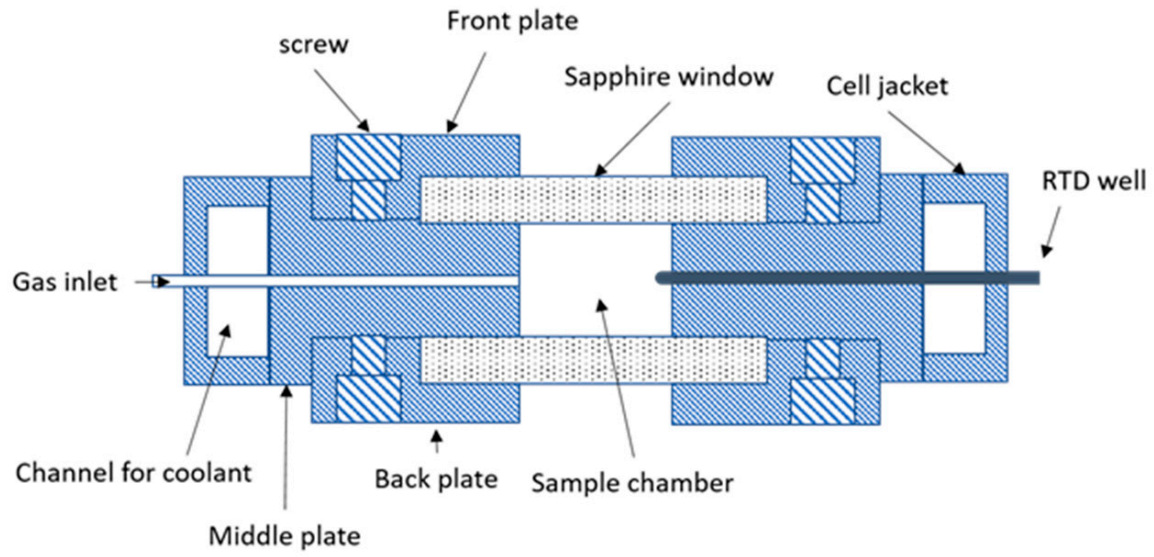

Figure 10. High-pressure optical cell (HPOC) for spectroscopy studies.

The thermodynamics of the hydrate-formation/dissociation can be studied using a high-pressure micro-differential scanning calorimeter. In this system, the pressure can be gauged between $0.1-60 \mathrm{MPa}$, and the temperature can be controlled accurately $\left( \pm 0.05^{\circ} \mathrm{C}\right)$ in the range of -160 to $200{ }^{\circ} \mathrm{C}$. For the high-pressure DSC sample cell with inner volume of $4 \mathrm{~mL}$ was composed of a specific alloy or ceramics to eliminate corrosion or contamination $[62,65]$.

\subsection{Hydrate-Storage Designs}

After formation of the hydrate, there is a need to store the hydrate in container which can provide the required pressure and temperature in the stability range of the hydrate. Although no actual working plant for hydrogen storage in hydrate exists, there are some conceptual designs suggested to store hydrogen in gas hydrate. Shibata et al. suggested the idea of storing hydrogen in a sII hydrate inside a large-capacity underground silos. The hydrogen can supplied from various factories in the industrial zone close to 
the hydrate-production and storage plant. Figure 11 represents an underground storage tunnel where the formed hydrate can be stored. These tunnels are equipped with cooling systems, high-pressure storage tanks, and the facility to load/unload the formed hydrate granules [66].

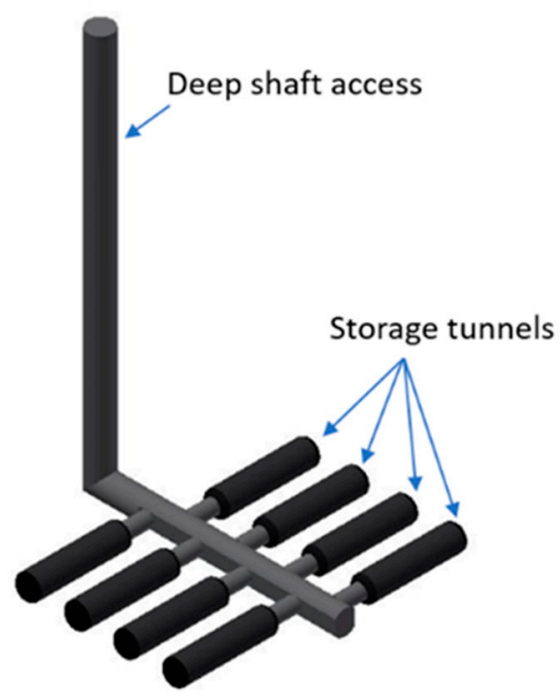

Figure 11. Layouts of storage tunnels using deep shafts.

Figure 12 also represents another design for storing the formed hydrates in aboveground storage tanks suggested by Ozaki et al [67]. In this design, to sustain the temperature of the tank under $0.11 \mathrm{MPa}$ hydrogen pressure at $140 \mathrm{~K}$, a gas-circulation system is employed to chill down the hydrogen by LNG vaporisation. This tank is equipped with a screw-conveyer for unloading the hydrate while the fresh hydrate can be loaded from the rotary stacker on the top of the tank. The hydrate can be supplied from a neighbouring hydrate-production plant, and, in response to demand, unloaded from the tank to a neighbouring regasification plant. It is worth mentioning that, due to the high diffusivity of hydrogen, and to avoid any leakage, the major portion of the facilities is a cylindrical triple-wall tank insulated by perlite concrete blocks [67].

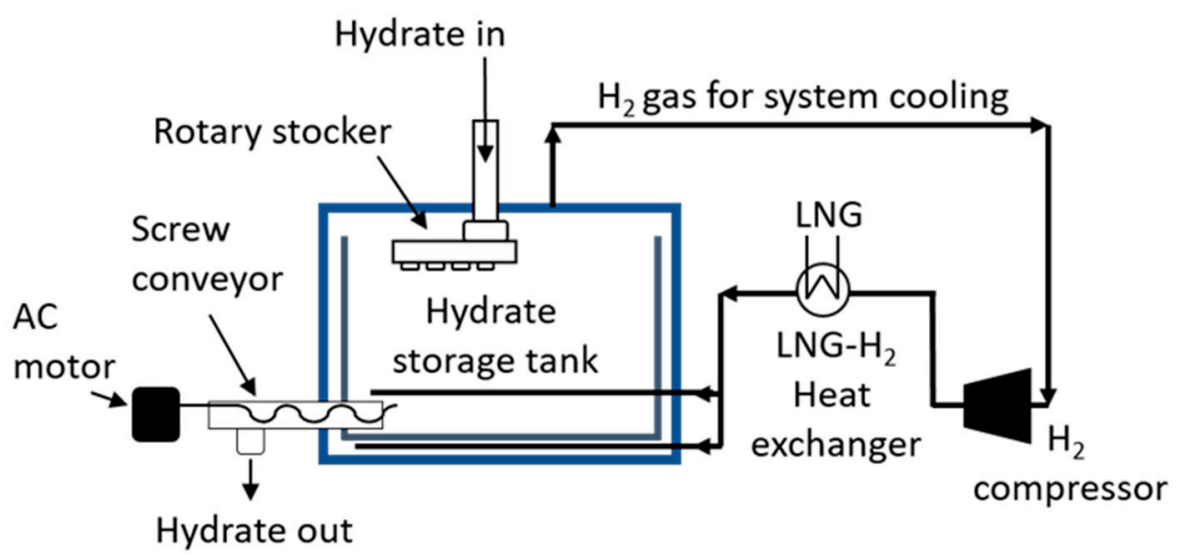

Figure 12. Schematic of hydrogen-hydrate storage facilities composed of a cylindrical, above-ground storage tank and a refrigeration system with hydrogen.

Table 1 summarizes the features of discussed reactors for hydrate formation and their potential in hydrogen storage. The designs with water dispersion was found to be more suitable for hydrogen storage due to the formation of small pieces of hydrates which will provide sufficient free surfaces for hydrogen uptake or release. Many designs are 
dispersing gas in a large volume of water, which is useful for many other applications, such as water treatment or dewatering. Indeed, the formation of a big slabs of hydrate will make it unsuitable for hydrogen storage application, and so an extra step of hydrate crushing is being used for gas adsorption/desorption applications.

Table 1. Hydrate formation reactors, advantages and disadvantages.

\begin{tabular}{|c|c|c|c|}
\hline \multicolumn{2}{|c|}{ Reactor } & \multicolumn{2}{|r|}{ Features } \\
\hline Water dispersion & & + & $\begin{array}{l}\text { Forming small hydrate droplets = Fast } \\
\text { hydrogen charge } / \text { discharge }\end{array}$ \\
\hline & Water-Spraying Reactor & $\begin{array}{l}+ \\
+ \\
-\end{array}$ & $\begin{array}{l}\text { Fast formation rate } \\
\text { Suitable for continuous generation } \\
\text { Difficult heat dispersion }\end{array}$ \\
\hline \multirow[t]{6}{*}{ Gas dispersion } & & + & $\begin{array}{l}\text { Forming bulky hydrate = Slow hydrogen } \\
\text { charge } / \text { discharge }\end{array}$ \\
\hline & Stirred-Tank Reactor & $\begin{array}{l}+ \\
+ \\
+ \\
-\end{array}$ & $\begin{array}{l}\text { Common in research reactors } \\
\text { Suitable for water treatment applications } \\
\text { Suitable for dewatering (solid/water } \\
\text { separation) } \\
\text { Slow formation rate }\end{array}$ \\
\hline & Bubbling Reactor & $\begin{array}{l}+ \\
+\end{array}$ & $\begin{array}{l}\text { Gas injection from bottom } \\
\text { Fast formation rate }\end{array}$ \\
\hline & Water-in-Oil Emulsion & + & Suitable for two component hydrates \\
\hline & Fixed-Bed Reactor & + & $\begin{array}{l}\text { Extra solid additive for hydrate } \\
\text { nucleation }\end{array}$ \\
\hline & Unidirectional Growth & $\begin{array}{l}+ \\
+ \\
-\end{array}$ & $\begin{array}{l}\text { Suitable for desalination, } \\
\text { Suitable for heavily polluted wastewater } \\
\text { treatment } \\
\text { Slow formation rate }\end{array}$ \\
\hline
\end{tabular}

\section{Conclusions}

Bearing all available designs in mind, it can be concluded that interdisciplinary approach will play a main role in developing gas hydrate in gas storage application. A broad knowledge of materials science, surface engineering, fluid dynamics and process design is required to address the challenges allied with large-scale hydrate formation. The most common and potentially fruitful collaboration is between chemists and chemical engineers where the knowledge on gas hydrate behavior, accelerated formation, and extended stability will meet the engineering aspects of reactor design, hydrate formation and storage.

Future studies in this area can be categorised in one of the following main subjects:

- Laboratory work from micro to macro scales: On a molecular and micro scale, it would be highly desirable to determine the influence of additives on $\mathrm{H}_{2}$-hydrate formation kinetics, in addition to thermodynamic properties, structure, composition, and cage occupancy of the resulting hydrate phase; the molecular-migration behaviour of the $\mathrm{H}_{2}$ 
molecules in the hydrate phase requires detailed study. Also, the interaction between additives and the hydrate phase needs to be investigated. Various analytical methods, such as Raman spectroscopy, differential-scanning calorimetry, and X-ray diffraction need to be considered. On a medium to large scale, the efficiency of $\mathrm{H}_{2}$-hydrate formation with respect to $\mathrm{H}_{2}$-storage capacity, hydrate-formation kinetics, as well as phase equilibrium, require investigation using high-pressure autoclaves. This background experimental data could, and, indeed, should, be used for important mechanistic and parametric modelling, to increase our level of insight into fundamentals of hydrate formation in the context of scaled-up hydrate reactors.

- Molecular-dynamics simulation: Based on experimental data, molecular-dynamics (MD) simulations need to be performed to ascertain and elucidate crystallisation mechanisms of hydrogen hydrates. Indeed, insights from experiments can be used to inform and parameterise force-fields for MD, so as to allow MD to replicate as closely as possible experimental findings. Based on such insights into molecular mechanisms, it will be possible to assess free-energy profiles for transitions to the hydrate state, as well as to restructuring of water in the hydration layers around promotors and additives.

Author Contributions: Conceptualization, M.R.G. and N.J.E.; writing—original draft preparation, M.R.G., J.M.S.; writing—review and editing, M.R.G., J.M.S. and N.J.E.; visualization, M.R.G.; supervision, N.J.E. All authors have read and agreed to the published version of the manuscript.

Funding: This research received no external funding.

Institutional Review Board Statement: Not applicable.

Informed Consent Statement: Not applicable.

Data-Availability Statement: No new data were created or analyzed in this study. Data sharing is not applicable to this article.

Conflicts of Interest: The authors declare no conflict of interest.

\section{References}

1. Crabtree, G.W.; Dresselhaus, M.S.; Buchanan, M.V. The Hydrogen Economy. Phys. Today 2004, 57, 39-44. [CrossRef]

2. Modisha, P.M.; Ouma, C.N.M.; Garidzirai, R.; Wasserscheid, P.; Bessarabov, D. The Prospect of Hydrogen Storage Using Liquid Organic Hydrogen Carriers. Energy Fuels 2019, 33, 2778-2796. [CrossRef]

3. Stackelberg, M.V. Feste gashydrate. Naturwissenschaften 1949, 36, 327-333. [CrossRef]

4. Mao, W.L.; Mao, H.-K.; Goncharov, A.F.; Struzhkin, V.V.; Guo, Q.; Hu, J.; Shu, J.; Hemley, R.J.; Somayazulu, M.; Zhao, Y. Hydrogen Clusters in Clathrate Hydrate. Science 2002, 297, 2247-2249. [CrossRef]

5. Lee, H.; Lee, J.-W.; Kim, D.Y.; Park, J.; Seo, Y.-T.; Zeng, H.; Moudrakovski, I.; Ratcliffe, C.I.; Ripmeester, J.A. Tuning clathrate hydrates for hydrogen storage. Nat. Cell Biol. 2005, 434, 743-746. [CrossRef]

6. Zhong, J.-R.; Chen, L.-T.; Liu, T.-C.; Zeng, X.-Y.; Sun, Y.-F.; Sun, C.-Y.; Liu, B.; Chen, G.-J.; Ripmeester, J.A. Sieving of HydrogenContaining Gas Mixtures with Tetrahydrofuran Hydrate. J. Phys. Chem. C 2017, 121, 27822-27829. [CrossRef]

7. Prasad, P.S.R.; Sugahara, T.; Sum, A.K.; Sloan, E.D.; Koh, C.A. Hydrogen Storage in Double Clathrates withtert-Butylamine. J. Phys. Chem. A 2009, 113, 6540-6543. [CrossRef]

8. Veluswamy, H.P.; Kumar, R.; Linga, P. Hydrogen storage in clathrate hydrates: Current state of the art and future directions. Appl. Energy 2014, 122, 112-132. [CrossRef]

9. Grim, R.G.; Barnes, B.C.; Lafond, P.G.; Kockelmann, W.A.; Keen, D.A.; Soper, A.K.; Hiratsuka, M.; Yasuoka, K.; Koh, C.A.; Sum, A.K. Observation of Interstitial Molecular Hydrogen in Clathrate Hydrates. Angew. Chem. Int. Ed. 2014, 53, 10710-10713. [CrossRef]

10. Ahn, Y.-H.; Moon, S.; Koh, D.-Y.; Hong, S.; Lee, H.; Lee, J.W.; Park, Y. One-step formation of hydrogen clusters in clathrate hydrates stabilized via natural gas blending. Energy Storage Mater. 2020, 24, 655-661. [CrossRef]

11. Nguyen, T.T.; Pétuya, C.; Talaga, D.; Desmedt, A. Promoting the Insertion of Molecular Hydrogen in Tetrahydrofuran Hydrate With the Help of Acidic Additives. Front. Chem. 2020, 8, 550862. [CrossRef] [PubMed]

12. Desmedt, A.; Martin-Gondre, L.; Nguyen, T.T.; Pétuya, C.; Barandiaran, L.; Babot, O.; Toupance, T.; Grim, R.G.; Sum, A.K. Modifying the Flexibility of Water Cages by Co-Including Acidic Species within Clathrate Hydrate. J. Phys. Chem. C 2015, 119, 8904-8911. [CrossRef]

13. Trueba, A.T.; Radovic, I.; Zevenbergen, J.F.; Kroon, M.C.; Peters, C.C. Kinetics measurements and in situ Raman spectroscopy of formation of hydrogen-tetrabutylammonium bromide semi-hydrates. Int. J. Hydrogen Energy 2012, 37, 5790-5797. [CrossRef] 
14. Trueba, A.T.; Radovic, I.; Zevenbergen, J.F.; Peters, C.C.; Kroon, M.C. Kinetic measurements and in situ Raman spectroscopy study of the formation of TBAF semi-hydrates with hydrogen and carbon dioxide. Int. J. Hydrogen Energy 2013, 38, 7326-7334. [CrossRef]

15. Veluswamy, H.P.; Linga, P. Macroscopic kinetics of hydrate formation of mixed hydrates of hydrogen/tetrahydrofuran for hydrogen storage. Int. J. Hydrogen Energy 2013, 38, 4587-4596. [CrossRef]

16. Malet-Sanz, L.; Susanne, F. Continuous Flow Synthesis. A Pharma Perspective. J. Med. Chem. 2012, 55, 4062-4098. [CrossRef]

17. Razzaq, T.; Kappe, C.O. Continuous Flow Organic Synthesis under High-Temperature/Pressure Conditions. Chem. Asian J. 2010, 5, 1274-1289. [CrossRef]

18. Wegner, J.; Ceylan, S.; Kirschning, A. Flow Chemistry-A Key Enabling Technology for (Multistep) Organic Synthesis. Adv. Synth Catal. 2012, 354, 17-57. [CrossRef]

19. Tortoioli, S.; Friedli, A.; Prud'Homme, A.; Richard-Bildstein, S.; Kohler, P.; Abele, S.; Vilé, G. Development of an efficient and sustainable synthesis of 2-(3-methyl-1H-1,2,4-triazol-1-yl) acetic acid under continuous-flow conditions. Green Chem. 2020, 22, 3748-3758. [CrossRef]

20. Wiles, C.; Watts, P. Continuous flow reactors: A perspective. Green Chem. 2012, 14, 38-54. [CrossRef]

21. Porta, R.; Benaglia, M.; Puglisi, A. Flow Chemistry: Recent Developments in the Synthesis of Pharmaceutical Products. Org. Process. Res. Dev. 2016, 20, 2-25. [CrossRef]

22. Jones, R.V.; Godorhazy, L.; Varga, N.; Szalay, D.; Urge, A.L.; Darvas, F. Continuous-Flow High Pressure Hydrogenation Reactor for Optimization and High-Throughput Synthesis. J. Comb. Chem. 2006, 8, 110-116. [CrossRef] [PubMed]

23. Hould, N.; Elanany, M.S.; Aleisa, R.M.; Al-Majnouni, K.A.; Al-Malki, A.; Abba, I. Evaluating polymeric inhibitors of ethane clathrate hydrates. J. Nat. Gas Sci. Eng. 2015, 24, 543-549. [CrossRef]

24. Vysniauskas, A.; Bishnoi, P. A kinetic study of methane hydrate formation. Chem. Eng. Sci. 1983, 38, 1061-1072. [CrossRef]

25. Tang, L.-G.; Li, X.-S.; Feng, Z.-P.; Lin, A.Y.-L.; Fan, S.-S. Natural Gas Hydrate Formation in an Ejector Loop Reactor: Preliminary Study. Ind. Eng. Chem. Res. 2006, 45, 7934-7940. [CrossRef]

26. Takahashi, M.; Kawamura, T.; Yamamoto, Y.; Ohnari, H.; Himuro, S.; Shakutsui, H. Effect of Shrinking Microbubble on Gas Hydrate Formation. J. Phys. Chem. B 2003, 107, 2171-2173. [CrossRef]

27. Havelka, P.; Linek, V.; Sinkule, J.; Zahradník, J.; Fialova, M. Effect of the ejector configuration on the gas suction rate and gas hold-up in ejector loop reactors. Chem. Eng. Sci. 1997, 52, 1701-1713. [CrossRef]

28. Xin, Y.; Zhang, J.; He, Y.; Wang, C. Modelling and experimental study of hydrate formation kinetics of natural gas-water-surfactant system in a multi-tube bubble column reactor. Can. J. Chem. Eng. 2019, 97, 2765-2776. [CrossRef]

29. You, R.; Li, H.; Tao, Z. Experimental investigation on two-dimensional heat transfer and secondary flow in a rotating smooth channel. Int. J. Heat Mass Transf. 2017, 113, 342-353. [CrossRef]

30. Wei, K.; Tao, Z.; Wu, H.; Xu, G.; Li, H.; You, R. Interaction between the primary flow fields and the secondary flow fields under rotating condition. Exp. Therm. Fluid Sci. 2017, 84, 217-230. [CrossRef]

31. Zhai, Y.; Li, Z.; Wang, H.; Xie, G. Analysis of field synergy principle and the relationship between secondary flow and heat transfer in double-layered microchannels with cavities and ribs. Int. J. Heat Mass Transf. 2016, 101, 190-197. [CrossRef]

32. Guo, J.; Huai, X. Numerical investigation of helically coiled tube from the viewpoint of field synergy principle. Appl. Therm. Eng. 2016, 98, 137-143. [CrossRef]

33. Guo, J.; Xu, M.; Cheng, L. Numerical investigations of circular tube fitted with helical screw-tape inserts from the viewpoint of field synergy principle. Chem. Eng. Process. Process. Intensif. 2010, 49, 410-417. [CrossRef]

34. Ghaani, M.R.; Kusalik, P.G.; English, N.J. Massive generation of metastable bulk nanobubbles in water by external electric fields. Sci. Adv. 2020, 6, eaaz0094. [CrossRef] [PubMed]

35. Liu, H.; Zhan, S.; Li, R.; Liu, Y.; Guo, P.; Wang, Z.; Du, J.; Wen, Y.; Dai, P.; Liao, H. High-efficiency natural-gas storage method involving formation of gas hydrate in water/oil-cyclopentane emulsion. Chem. Eng. J. 2020, 400, 125369. [CrossRef]

36. Liu, H.; Wang, J.; Chen, G.; Liu, B.; Dandekar, A.; Wang, B.; Zhang, X.; Sun, C.; Ma, Q.-L. High-efficiency separation of a CO2/H2 mixture via hydrate formation in W/O emulsions in the presence of cyclopentane and TBAB. Int. J. Hydrogen Energy 2014, 39, 7910-7918. [CrossRef]

37. Liu, H.; Mu, L.; Wang, B.; Liu, B.; Wang, J.; Zhang, X.; Sun, C.; Chen, J.; Jia, M.; Chen, G. Separation of ethylene from refinery dry gas via forming hydrate in w/o dispersion system. Sep. Purif. Technol. 2013, 116, 342-350. [CrossRef]

38. Liu, H.; Mu, L.; Liu, B.; Zhang, X.; Wang, J.; Wang, B.; Sun, C.; Yang, L.; Wang, H.; Xiao, P.; et al. Experimental Studies of the Separation of $\mathrm{C} 2$ Compounds from CH4 + C2H4 + C2H6 + N2 Gas Mixtures by an Absorption-Hydration Hybrid Method. Ind. Eng. Chem. Res. 2013, 52, 2707-2713. [CrossRef]

39. Di Profio, P.; Canale, V.; Germani, R.; Arca, S.; Fontana, A. Reverse micelles enhance the formation of clathrate hydrates of hydrogen. J. Colloid Interface Sci. 2018, 516, 224-231. [CrossRef]

40. Greaves, D.; Boxall, J.; Mulligan, J.; Sloan, E.D.; Koh, C.A. Hydrate formation from high water content-crude oil emulsions. Chem. Eng. Sci. 2008, 63, 4570-4579. [CrossRef]

41. Di Profio, P.; Arca, S.; Rossi, F.; Filipponi, M. Comparison of hydrogen hydrates with existing hydrogen storage technologies: Energetic and economic evaluations. Int. J. Hydrogen Energy 2009, 34, 9173-9180. [CrossRef]

42. Murakami, T.; Kuritsuka, H.; Fujii, H.; Mori, Y.H. Forming a Structure-H Hydrate Using Water and Methylcyclohexane Jets Impinging on Each Other in a Methane Atmosphere. Energy Fuels 2009, 23, 1619-1625. [CrossRef] 
43. Khokhar, A.; Gudmundsson, J.; Sloan, E. Gas storage in structure H hydrates. Fluid Phase Equilibria 1998, 150-151, 383-392. [CrossRef]

44. Mori, Y.H.; Nagai, K.; Funaba, H.; Komotori, K. Cooling of Freely Falling Liquid Drops with a Shell of an Immiscible Volatile Liquid. J. Heat Transf. 1981, 103, 508-513. [CrossRef]

45. Adeyemo, A.; Kumar, R.; Linga, P.; Ripmeester, J.; Englezos, P. Capture of carbon dioxide from flue or fuel gas mixtures by clathrate crystallization in a silica gel column. Int. J. Greenh. Gas Control. 2010, 4, 478-485. [CrossRef]

46. Babu, P.; Kumar, R.; Linga, P. Pre-combustion capture of carbon dioxide in a fixed bed reactor using the clathrate hydrate process. Energy 2013, 50, 364-373. [CrossRef]

47. Kumar, A.; Kumar, R. Role of Metallic Packing and Kinetic Promoter in Designing a Hydrate-Based Gas Separation Process. Energy Fuels 2015, 29, 4463-4471. [CrossRef]

48. Kumar, A.; Sakpal, T.; Linga, P.; Kumar, R. Influence of contact medium and surfactants on carbon dioxide clathrate hydrate kinetics. Fuel 2013, 105, 664-671. [CrossRef]

49. Park, S.; Lee, S.; Lee, Y.; Lee, Y.; Seo, Y. Hydrate-based pre-combustion capture of carbon dioxide in the presence of a thermodynamic promoter and porous silica gels. Int. J. Greenh. Gas Control. 2013, 14, 193-199. [CrossRef]

50. Kang, S.-P.; Lee, J.; Seo, Y. Pre-combustion capture of CO2 by gas hydrate formation in silica gel pore structure. Chem. Eng. J. 2013, 218, 126-132. [CrossRef]

51. Song, Y.; Wang, X.; Yang, M.; Jiang, L.; Liu, Y.; Dou, B.; Zhao, J.; Wang, S. Study of Selected Factors Affecting Hydrate-Based Carbon Dioxide Separation from Simulated Fuel Gas in Porous Media. Energy Fuels 2013, 27, 3341-3348. [CrossRef]

52. Babu, P.; Linga, P.; Kumar, R.; Englezos, P. A review of the hydrate based gas separation (HBGS) process for carbon dioxide pre-combustion capture. Energy 2015, 85, 261-279. [CrossRef]

53. Muraoka, M.; Susuki, N.; Yamamoto, Y. Evaluation of the performance of kinetic inhibitors for clathrate hydrate using unidirectional growth apparatus. RSC Adv. 2016, 6, 63880-63885. [CrossRef]

54. Ohmura, R.; Kashiwazaki, S.; Shiota, S.; Tsuji, H.; Mori, Y.H. Structure-I and Structure-H Hydrate Formation Using Water Spraying. Energy Fuels 2002, 16, 1141-1147. [CrossRef]

55. Tsuji, H.; Ohmura, R.; Mori, Y.H. Forming Structure-H Hydrates Using Water Spraying in Methane Gas: Effects of Chemical Species of Large-Molecule Guest Substances. Energy Fuels 2004, 18, 418-424. [CrossRef]

56. Rossi, F.; Filipponi, M.; Castellani, B. Investigation on a novel reactor for gas hydrate production. Appl. Energy 2012, 99, 167-172. [CrossRef]

57. Li, G.; Liu, D.; Xie, Y.; Xiao, Y. Study on Effect Factors for CO2Hydrate Rapid Formation in a Water-Spraying Apparatus. Energy Fuels 2010, 24, 4590-4597. [CrossRef]

58. Fukumoto, K.; Tobe, J.-I.; Ohmura, R.; Mori, Y.H. Hydrate formation using water spraying in a hydrophobic gas: A preliminary study. AIChE J. 2001, 47, 1899-1904. [CrossRef]

59. Matsuda, S.; Tsuda, H.; Mori, Y.H. Hydrate formation using water spraying onto a cooled solid surface in a guest gas. AIChE J. 2006, 52, 2978-2987. [CrossRef]

60. Schicks, J.M.; Pan, M.; Giese, R.; Poser, M.; Ismail, N.A.; Luzi-Helbing, M.; Bleisteiner, B.; Lenz, C. A new high-pressure cell for systematic in situ investigations of micro-scale processes in gas hydrates using confocal micro-Raman spectroscopy. Rev. Sci. Instrum. 2020, 91, 115103. [CrossRef]

61. Schicks, J.M.; Ripmeester, J.A. The Coexistence of Two Different Methane Hydrate Phases under Moderate Pressure and Temperature Conditions: Kinetic versus Thermodynamic Products. Angew. Chem. Int. Ed. 2004, 43, 3310-3313. [CrossRef] [PubMed]

62. Cai, J.; Tao, Y.-Q.; Von Solms, N.; Xu, C.-G.; Chen, Z.-Y.; Li, X.-S. Experimental studies on hydrogen hydrate with tetrahydrofuran by differential scanning calorimeter and in-situ Raman. Appl. Energy 2019, 243, 1-9. [CrossRef]

63. Ziparo, C.; Giannasi, A.; Ulivi, L.; Zoppi, M. Raman spectroscopy study of molecular hydrogen solubility in water at high pressure. Int. J. Hydrogen Energy 2011, 36, 7951-7955. [CrossRef]

64. Sakamoto, J.; Hashimoto, S.; Tsuda, T.; Sugahara, T.; Inoue, Y.; Ohgaki, K. Thermodynamic and Raman spectroscopic studies on hydrogen+tetra-n-butyl ammonium fluoride semi-clathrate hydrates. Chem. Eng. Sci. 2008, 63, 5789-5794. [CrossRef]

65. Cai, J.; Yan, R.; Xu, C.-G.; Chen, Z.-Y.; Li, X.-S. Formation and Dissociation Behavior Studies of Hydrogen Hydrate in the presence of Tetrahydrofuran by using High Pressure DSC. Energy Procedia 2019, 158, 5149-5155. [CrossRef]

66. Shibata, T.; Yamachi, H.; Ohmura, R.; Mori, Y.H. Engineering investigation of hydrogen storage in the form of a clathrate hydrate: Conceptual designs of underground hydrate-storage silos. Int. J. Hydrogen Energy 2012, 37, 7612-7623. [CrossRef]

67. Ozaki, M.; Tomura, S.; Ohmura, R.; Mori, Y.H. Comparative study of large-scale hydrogen storage technologies: Is hydrate-based storage at advantage over existing technologies? Int. J. Hydrogen Energy 2014, 39, 3327-3341. [CrossRef] 